\title{
AERIAL RADIOLOGICAL MEASURING SURVEY OF THE AREA SURROUNDING THE SHIPPINGPORT ATOMIC POWER STATION, SHIPPINGPORT, PENNSYLVANIA FEBRUARY 1973
}

\author{
EG\&G, Inc., Las Vegas, Nevada
}

This report was prepared as an account of work
sponsered by the United States Government. Neither
the United States nor the Unted States Atomic Energy
Commission, nor any of thenr employes, nor any of
their contractors, subcontractors, or then employees,
makes any warranty, express or implied, or assumes any
legal liability or responsibility for the accuracy, conn-
pleteness or usefulness of any information, apparatus.
product or process disclosed, or represents that its use
would not infringe privately owned rights.

This report is part of a series on the continuing activities of the Aerial Radiological Measuring System operated for the U.S. Atomic Energy Commission. The ARMS program is managed by the Division of Operational Safety and is a cooperative effort among various offices and divisions of the Commission. 


\section{DISCLAIMER}

This report was prepared as an account of work sponsored by an agency of the United States Government. Neither the United States Government nor any agency Thereof, nor any of their employees, makes any warranty, express or implied, or assumes any legal liability or responsibility for the accuracy, completeness, or usefulness of any information, apparatus, product, or process disclosed, or represents that its use would not infringe privately owned rights. Reference herein to any specific commercial product, process, or service by trade name, trademark, manufacturer, or otherwise does not necessarily constitute or imply its endorsement, recommendation, or favoring by the United States Government or any agency thereof. The views and opinions of authors expressed herein do not necessarily state or reflect those of the United States Government or any agency thereof. 


\section{DISCLAIMER}

Portions of this document may be illegible in electronic image products. Images are produced from the best available original document. 
WORK PERFORMED BY

Instrumentation Specialist

W. F. Verheyden

$\underline{\text { Navigator }}$

M. D. Sevart

Pilot

E. D. Shultz

\section{$\underline{\text { Scientists }}$}

P. K. Boyns

A. E. Fritzsche

II. A. Wollenberg 


\begin{abstract}
The Aexial Radiological Measuring System (ARMS) was used to survey the Shippingport Atomic Power Station and surrounding area on February 24, 1973. The survey measured terrestrial background gamma radiation.

A high-sensitivity detection system collected gamma-ray spectral and gross-count data. The data were then computer processed into a map of a 530 square mile area showing isoexposure contours three feet above the ground. Results indicated the presence of isotopes normally found in the background radiation throughout the United States.
\end{abstract}

\title{
ACKNOWLEDGMENTS
}

Special appreciation is given to L. J. Deal (Assistant Director, DOS/Health Protection, USAEC) and to Dr. Charles Pelletier (Chief, Environmental Inspection Branch, Regulatory Operations, USAEC) for their support and encouragement in this program. 
CONTENTS

1.

INTRODUCTION. $\quad . \quad . \quad \cdot \quad \cdot \quad \cdot \quad \cdot \quad \cdot \quad \cdot 1$

1.1 Identification of Surveyed Plant and Area . . 1

1.2 ARMS Program . . . . . . . . 1

1.3 ARMS Equipment and Procedures . . . . 1

1.4 Reduction and Presentation of Data . . . . 4

2. REACTOR AND SITE CHARACTERISTICS . . . . 5

2.1 Reactor Characteristics . . . . . . 5

2.2 Site Area Characteristics . . . . . . . 6

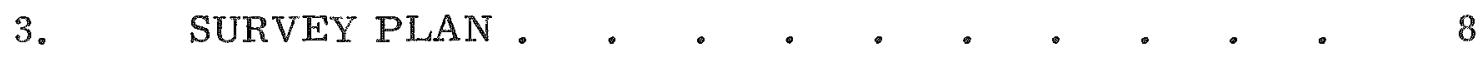

3.1 Specification of Flight Lines . . . . . $\quad 8$

3.2 Coordination with Local Authorities. . . . 8

4. RADIOLOGICAL SURVEY • • • • • •

4.1 Survey Missions . . . . . . . . 9

4.2 Gross-Count Data. . . . . . . . 9

4.3 Spectral Data. . . . . . . . . 11

4.4 Soil Sample Measurements. . . . . . 11

5. SUMMARY AND CONCLUSIONS • . . $\quad$ • . 14 


\section{INTRODUCTION}

\subsection{Identification of Surveyed Plant and Area}

The Aerial Radiological Measuring System (ARMS) (Ref. 1) operated by EG\&G, Inc., Las Vegas, Nevada, for the U. S. Atomic Energy Commission was used to survey an extensive area surrounding the Shippingport Atomic Power Station on February 24, 1973. The Shippingport Station, operated by the Atomic Energy Commission and the Duquesne Light Company, is located near Shippingport, Pennsylvania. The size of the survey area was 530 square miles.

\subsection{ARMS Program}

The present survey was made as part of a continuing nationwide ARMS program started in 1958 to monitor radiation levels surrounding facilities producing or utilizing radioactive materials. This survey is the first such performed in the Shippingport area since the station began operation in 1957.

The detection system on board the aircraft collects gamma-ray gross-count and spectral data on each flight line of the survey. The gamma radiation and aircraft position information are processed by a computer into an isoexposure contour map of the area surveyed.

\subsection{ARMS Equipment and Procedures}

The ARMS aircraft and its on-board radiation detection equipment were used in the survey of the Shippingport facility and surrounding area. Since the ARMS equipment and procedures have been discussed in detail elsewhere (Ref. 1), they will only be described briefly here.

The ARMS surveys are flown in a Beechcraft Twin Bonanza at an altitude of 300 to 500 feet above ground level at a ground speed of about 140 knots $(235 \mathrm{ft} / \mathrm{sec})$. The ground position of the aircraft and its altitude above terrain are measured and recorded every other second by a radar navigation computer system. The position and altitude measurements are accurate to $\pm 350 \mathrm{ft}$ and $\pm 5 \mathrm{ft}$, respectively.

A typical flight pattern consists of a series of parallel lines oriented in a north-south or east-west direction. The lines are spaced 
at intervals of one nautical mile (6080 feet) and cover all of the land area within a twelve and one-half nautical mile radius of the facility.

At an altitude of 500 feet, the field of view of the detectors is approximately $1 / 4$ mile wide for a mean gamma energy of naturally occurring isotopes.

The aerial radiation measurements are of two distinct types, made simultaneously: (1) gross gamma count (intensity) measurements and (2) gamma spectral measurements. The detector system consists of an array of fourteen $4 \times 4$ in. NaI (T $l$ ) scintillation crystals, each coupled to its own photomultiplier assembly. The detector system output is directed both to the gross gamma count computing system and to the multichannel spectrum analyzer. The data collecting system is shown in Figure 1.

The gross gamma count system consists of an amplifierdiscriminator-computer unit that counts and records the total number of gamma-rays of energy greater than $50 \mathrm{keV}$ that are detected during a 1 -second time interval. The gross gamma count rate (number of gamma-rays detected per second) is digitally recorded along with aircraft position and altitude every other second. Aircraft position data are supplied by a track navigational computer and doppler radar. Altitude above terrain is measured with a radar altimeter. As a backup and complement to the digital recording of the gross-count data, a record is made on a continuous strip chart of both gross gamma count rate and radar altitude as a function of distance. Typical gross-count rates for natural background are several thousand per second.

Whereas the gross gamma count data specify the intensity of radiation as a function of position, the gamma spectral data are useful in identifying particular radioactive isotopes. A pulse-height analyzer automatically sorts detected gamma-rays according to energy, thereby generating a number per unit-energy versus energy spectrum. Although gamma rays occur only at well known discrete energies characteristic of the cmitting species, air scattering tends to smear the detected distribution. Nevertheless, the characteristic peaks that permit isotope identification are readily observable. In wide area surveys, the typical acquisition time for a gamma-ray spectrum is several minutes; thus. the spectrum represents the average radiological properties of a tract several miles in length. However, if an area of interest is indicated by an increase of the gross gamma count data, spectral data acquisition times of only a few seconds are used to isolate the area spatially. If further investigation is warranted, a ground mobile unit with equipment similar to that in the aircraft is available to provide greater spatial and energy resolution. 


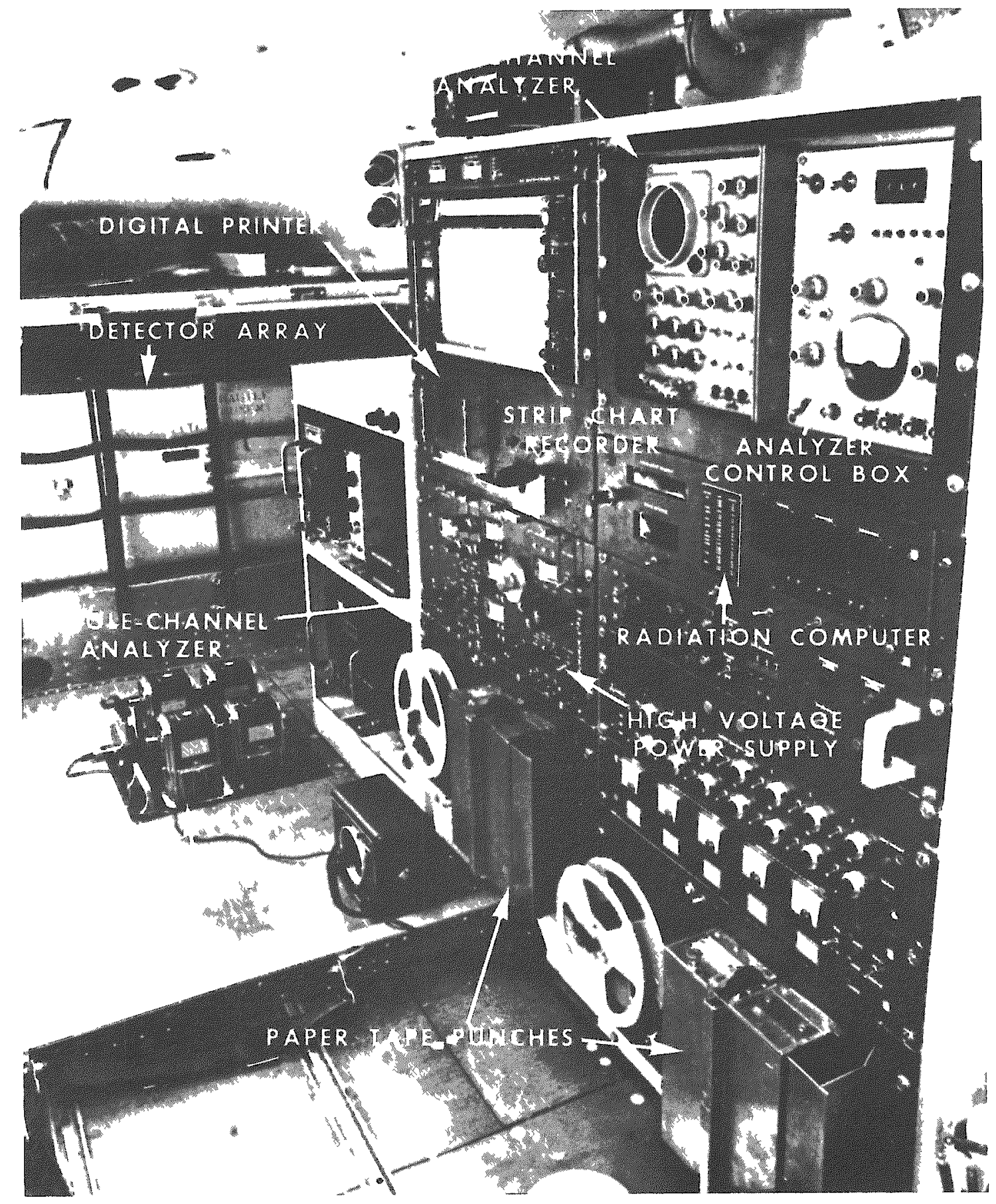

FIGURE 1. View of the interior of the Aerial Radiological Measuring Svstem (ARMS) aircrait showing detector package and electronic data collecion system. 
In addition to the equipment just described, the ARIS aircraft also carries an air sampling and analysis system, for the measurement of airborne radioactivity.

\subsection{Reduction and Presentation of Data}

The raw data from the gross gamma count and the gamma spectral measurements are permanently recorded on paper tape, which is computer processed and analyzed to characterize the radiological properties of the area surveyed. Using an altitude-dependent convcrsion factor obtained from prior calibration measurements, the raw gross-count rate is converted to exposure rate $(u \mathrm{R} / \mathrm{hr})$ at three feet above ground (designated as "terrestrial exposure rate").

The exposure rate conversion factor was obtained from repeated flights 200 to 1000 feet above terrain containing known distributions of natural isotopes. Such conversion factors have proved valid over distributed fission product fields, with a variation of less than $25 \%$. In practice, variations of $2 \mu \mathrm{R} / \mathrm{hr}$ or greater can be reliably observed in repeated flights over the same area. 


\section{REACTOR AND SITE CHARACTERISTICS}

\subsection{Reactor Characteristics}

The Shippingport Station is located in Beaver County, Pennsylvania, 20 miles north-west of Pittsburgh.

The principal nuclear contractor is the Westinghouse Electric Corporation. The facility is operated by the Atomic Energy Commission and the Duquesne Light Company.

Table 1 gives the specifications of the reactor facility at the time of the survey.

TABLE 1. Reactor facility specifications.

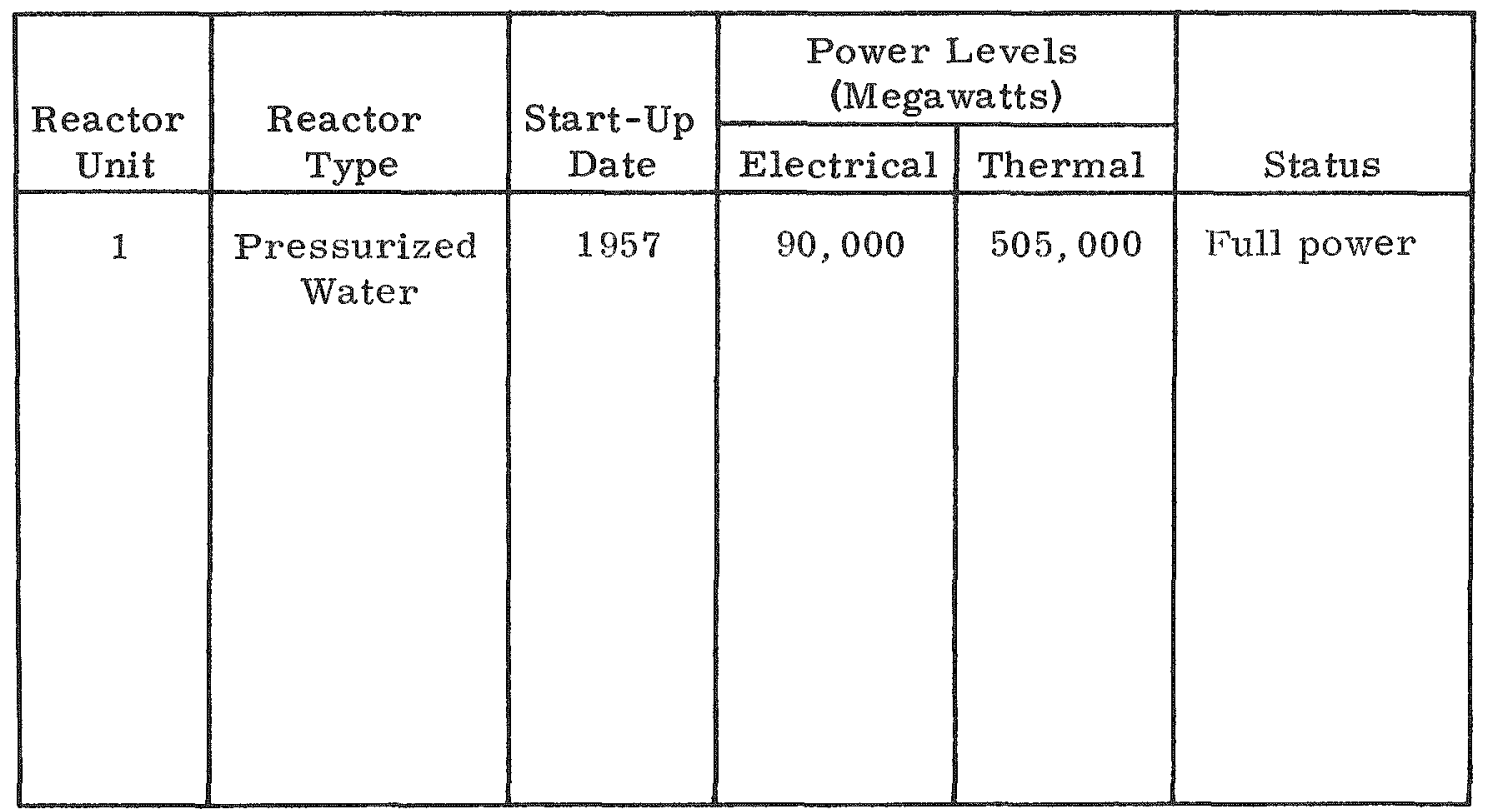




\section{$2.2 \quad$ Site Area Characteristics}

In general the terrain in the survey area consists of rough hills, with altitude variations of $300-400$ feet. Most of the land is wooded. Some small patches of snow were observed during the survey. Major rivers in the area are the Ohio and the Beaver.

'The principal geologic features of the region are nearly flat lying sedimentary units of Pennsylvania age. Beds of limestone alternate with sandstone and shale; interbedded coal layers are abundant. Pleistocene glacial deposits partially cover the older sedimentary units in the northwestern portion of the region. Most of the survey region is underlain by shale, sandstone, limestone, and some coal beds of the Conemagh Formation. Within the Ohio River valley and along major tributary streams, sandstone, shale, and limestone of the Allegheny Formation crop out.

Table 2 gives a breakdown of the population of the survey area in terms of distance and direction from the reactor site $(1970$ census figures -- Ref. 2). 
TABLE 2. Population distribution within the Shippingport Atomic Power Station area.

\begin{tabular}{|c|c|c|c|c|}
\hline \multirow[b]{3}{*}{ Town } & \multirow{3}{*}{$\begin{array}{l}\text { Direction from } \\
\text { Power Station }\end{array}$} & \multicolumn{3}{|c|}{ Population } \\
\hline & & \multicolumn{3}{|c|}{ Distance from Station (Miles) } \\
\hline & & $0-5$ & $5-10$ & $10-15$ \\
\hline Aliquippa, Pa. & $\mathrm{F}$ & & 22,277 & \\
\hline Ambridge, Pa. & ESH: & & & 11,324 \\
\hline Baden, Pa. & ENE & & & 5,536 \\
\hline Beaver, $\mathrm{Pa}$. & $\mathrm{NE}^{\mathrm{a}}$ & & 6,100 & \\
\hline Carnot, Pa. & $\mathrm{SE}$ & & & 13,093 \\
\hline Chester. W. Va. & W & & 3,614 & \\
\hline Clinton, Pa. & $\mathrm{SE}$ & & & 575 \\
\hline Darlington, Pa. & $\mathbb{N}$ & & & 344 \\
\hline L. Iiverpool, Ohif & $W$ & & 19,878 & \\
\hline Empire, Ohio & SW & & & 551 \\
\hline Frankfort & & & & \\
\hline Springs, $\mathrm{Pa}$. & $\mathrm{S}$ & & 144 & \\
\hline $\begin{array}{l}\text { Georgetown, } \mathrm{Pa} . \\
\text { Ilookstown, } \mathrm{Pa} \text {. }\end{array}$ & $\begin{array}{l}\text { W } \\
\text { SW }\end{array}$ & $\begin{array}{l}234 \\
246\end{array}$ & & \\
\hline 1.eetsdale, $\mathrm{Pa}$. & ESE & & & 1,862 \\
\hline Mayfield, Pa. & $\mathrm{NE}$ & & & 2,176 \\
\hline $\begin{array}{l}\text { Mechanicsburg, } \\
\mathrm{Pa}\end{array}$ & SSE & 9,385 & & \\
\hline Midland, Pa. & $\mathrm{N}$ & 5,271 & & \\
\hline Monaca, Pa. & NE & & 7,486 & \\
\hline New Brighton, $\mathrm{Pa}$ & $\mathrm{NE}$ & & & 7,637 \\
\hline $\begin{array}{c}\text { New Cumberland, } \\
\text { W Va. }\end{array}$ & SW & & & 1,865 \\
\hline New Galilee, $\mathrm{Pa}$. & $\mathrm{N}$ & & & 624 \\
\hline Ohioville, $\mathrm{Pa}$. & $\mathrm{NW}$ & 3,918 & & \\
\hline Rochester, Pa. & ENE & & & 4,819 \\
\hline Sewickley, $\mathrm{Pa}$. & $\mathrm{SE}$ & & & 5,660 \\
\hline Shippingport, Pa. & $\mathrm{NE}$ & 328 & & \\
\hline Toronto, Ohio & SW & & & 7,629 \\
\hline $\begin{array}{l}\text { Unionville, Pa. } \\
\text { Wellsville, Ohio }\end{array}$ & $\underset{W}{N}$ & & & $\begin{array}{r}375 \\
5.863\end{array}$ \\
\hline Totals & & 19,382 & 59,490 & 69,933 \\
\hline Grand Total & & & & 148,814 \\
\hline
\end{tabular}




\section{SURVEY PLAN}

\subsection{Specification of Flight Lines}

The flight pattern for the Shippingport survey consisted of 23 flight lines approximately $15-25$ nautical miles long and spaced one nautical mile apart. The flight lines were oriented in an east-west direction. Lines in the southern end of the survey area were cut short because of the controlled area near the Greater Pittsburgh Airport. Radiation data together with aircraft position and meteorological information were collected along each flight line.

\subsection{Coordination with Local Authorities}

ARMS survey missions are conducted under special waiver from the Federal Aviation Administration. The survey plan was discussed with the General Aviation District Office at Pittsburgh, and public announcements were published in the local newspapers prior to the survey operation in accordance with the FAA waiver for low-level flights.

The base of operations for the survey mission was Pittsburgh. 


\section{RADIOI,OGICAL SURVEY}

\subsection{Survey Missions}

The aerial survey of the Shippingport Station area was conducted on F'ebruary 24, 1973. This survey required a total flying time of 6 hours.

Gross-count and spectral data were simultaneously collected at an altitude of 500 feet. Spectral collections were accumulated over a 4 minute interval during which the aircraft traveled approximately 12 miles; consequently, two spectra per line were collected. For the shorter lines in the southern part of the survey, one spectrum per line was collected.

No lines were flown closer than one-half mile to the reactor site.

\subsection{Gross-Count Data}

As a first step in the analysis of the gross-count data, the background due to nonterrestrial radiation was subtracted. This background consists of cosmic-ray, aircraft, and airborne radioactivity contributions (Ref. 3). After correction for background, the data were normalized to a standard aix mass. The resultant net-count data were then converted to exposure rate in microroentgens per hour (UR/hr) at the 3 -foot level above the ground. The cosmic-ray exposure rate was then added back to the terrestrial exposure rate. Finally, the composite exposure rate data, together with aircraft position information, were processed into an isoexposure contour map for overlay on U. S. Geological Survey topographic maps of the survey area.

An isoexposure map of the Shippingport Station area is shown in Figure 2. The data shown on the map include a cosmic radiation contribution of $3.6 \mathrm{uR} / \mathrm{hr}$. Spatial resolution of the exposure rate data is determined by the field of view of the detector system, which is about $1 / 4$ mile.

Exposure rates are predominantly 6 to $10 \mu \mathrm{R} / \mathrm{hr}$ over the Conemagh Formation. Regions of somewhat lower radioactivity occur in the Ohio River valley and along major tributary streams such as Little Beaver Creek (running north from the Ohio River through Iredericktown). The lower radioactivity of these areas, predominantly 6 to $8 \mathrm{uR} / \mathrm{hr}$, may be attributed to Allegheny formation outcrops. The 


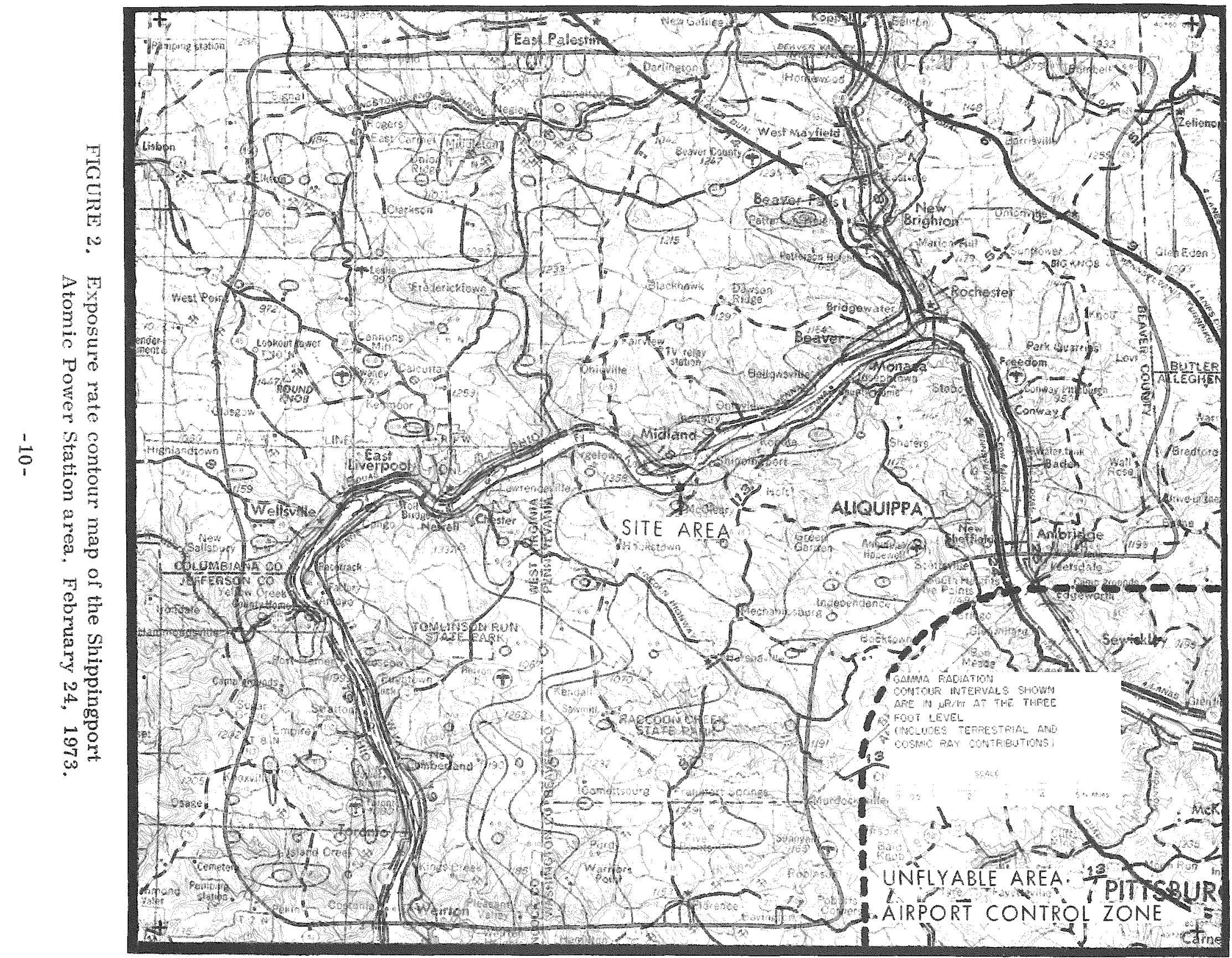


somewhat higher radioactivity areas (tending to $12 \mathrm{UR} / \mathrm{hr}$ ) near Warriors' Point and Florence in the southeastern portion of the survey region may be associated with shale, sandstone, and limestone of the Monongahela Formation. The spotty zones of relatively high radioactivity ( 8 to $12 \mathrm{uR} / \mathrm{hr}$ ) in the northwest portion of the region may reflect the presence of granitic material in glacial sediments associated with the southern limit of continental Pleistocene glaciation.

\subsection{Spectral Data}

Spectral data were recorded from about 0.03 to $3.0 \mathrm{MeV}$. The recording system was calibrated prior to takeoff with an yttrium-88 source, which emits two prominent gamma-rays of 0.898 and $1.836 \mathrm{MeV}$. The gain for each crystal in the 14-crystal detector array was set independently.

A spectrum typical of those taken during the survey is shown in Figure 3. Table 3 lists the prominent gamma-ray energies and associated source isotopes identified in the spectrum. Differences in shape between spectra taken over different portions of the survey area are minor, and the isotopes identified in all spectra are the same. Only isotopes consistent with normal background radiation are apparent.

\section{4. $4 \quad$ Soil Sample Measurements}

To provide a comparison with the aerial spectral data, soil samples from three locations in the survey area were collected for laboratory analysis. A high-resolution solid state Ge(Li) detector was used to perform gamma spectral measurements on the samples. These measurements will be reported separately (Ref. 4); preliminary results are consistent with the aerial spectral data.

The only gamma line present in the soil sample data not attributable to natural background radiation is one at $0.66 \mathrm{MeV}$ indicative of cesium-137. (In the aerial data this line cannot be clearly distinguished from the $0.61 \mathrm{MeV}$ line of bismuth-214, due to lack of resolution.) If the cesium came from the reactor, one would observe gamma lines from other long-lived fission products, such as the $0.36 \mathrm{MeV}$ line from iodine-131. Because of the absence of any such lines, the cesium is attributed to world-wide fallout from nuclear weapons testing. Radiation from cesium-137 is now a part of the normal terrestrial background. 


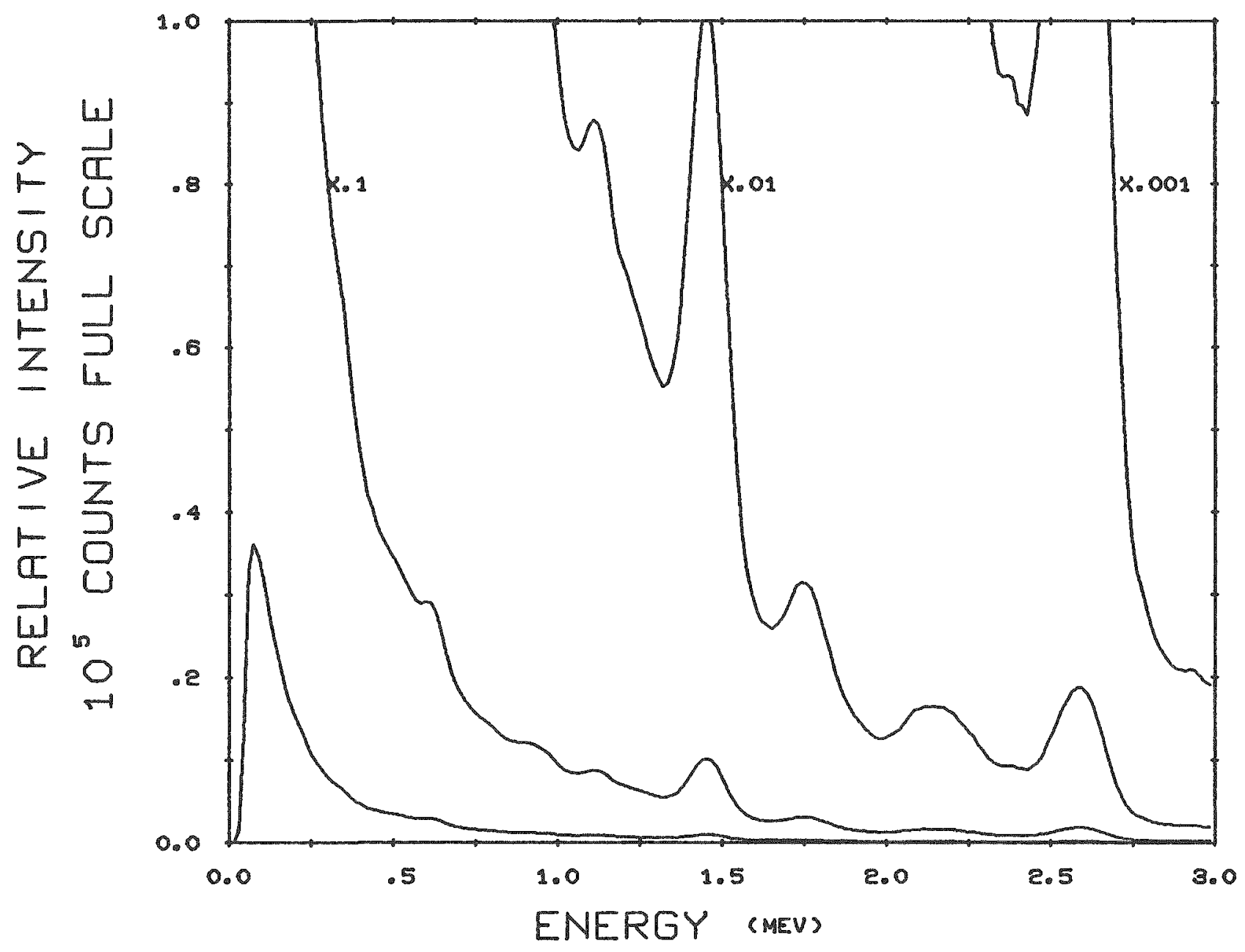

SPECTRUM NO: 7

DRTE OE-24-73

LIVE TIME 4.00

INTEGRATED CT. 524905.

TYPE ACFT TERRAIN BKG.-GND. DEPO. ALTITUDE $500 \mathrm{FT}$

AIRCRAFT (ARMS)

FIGURE 3. Typical spectrum for survey area. 
TABLE 3. Gamma-ray energies and isotopes consistent with spectral data of Figure 3.

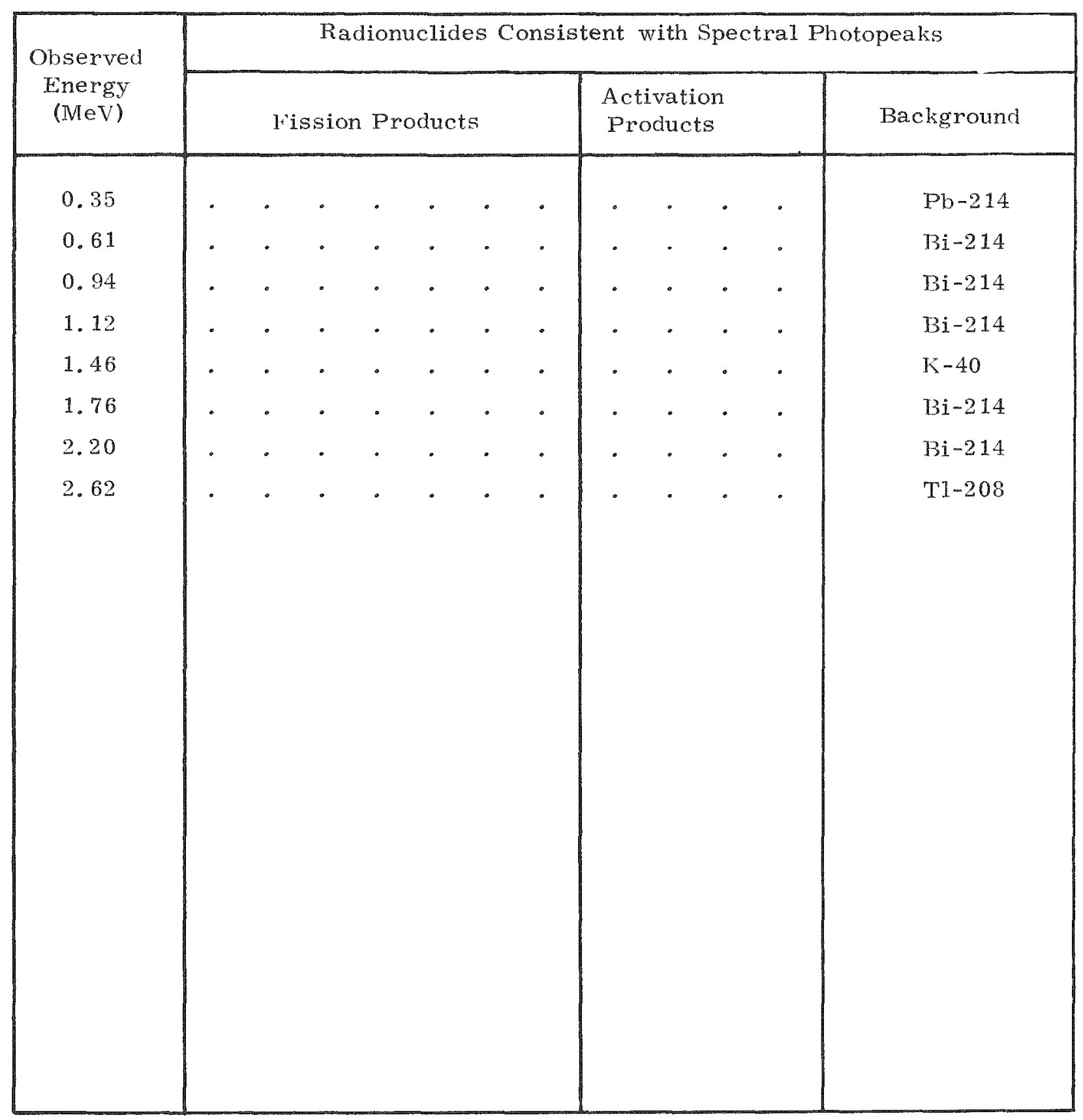




\section{SUMIMARY AND CONCLUSIONS}

The 530 square mile aerial survey of the area surrounding the Shippingport Station revealed that both the concentration and relative abundance of radioactive isotopes are consistent with normal background radiation and with the geology of the region. The 3 -foot level exposure rates mapped during the survey were mostly in the 4 to 12 uR/hr range.

No significant anomalies were detected that could be attributed to reactor operations. 


\section{RFFERENCES}

1. "Aerial Radiological Measuring Systems (ARMS) - Systems and Procedures Employed Through FJ71, "AEC Report No. ARMS-71.6, in preparation.

2. 1970 Census of Population, Advance Report PC(VI)-40, U. S. Dept. of Commerce, Bureau of Census, January 1971.

3. Burson, $Z$. G., Boyns, P. K., and Fritzsche, A. E., "Technical Procedures for Characterizing the Terrestrial Gamma Radiation Environment by Aerial Surveys, " FG\&G/LVAO Report No. 1183-1559, 1972 .

4. "Ground Based Observations Supporting the Shippingport Aerial Radiological Survey of 1973, "EG\&G/LVAO Report No. 1183-1577, in preparation. 